\title{
Ş,tefan Afloroaei, Privind altfel lumea celor absurde, Editura Humanitas, București, 2013, 214 p.
}

\author{
Cristinel Munteanu* \\ Facultatea de Comunicare și Relații Internaționale, Universitatea „Danubius”, Bd. Galați 3, 800654 Galaţi, România
}

Dintru început, titlul cărții profesorului Ștefan Afloroaei stîrnește imediat în mintea cititorului întrebări ca acestea: Cum altfel să privești lumea celor absurde? Despre ce (alt) fel de privire este vorba în acest caz? Cred că titlul ar putea fi reformulat astfel: Privind cu ințtelegere lumea celor absurde, în care sintagma $\mathrm{cu}$ ințtelegere nu trimite doar la procesul captării/revelării sensurilor lumii respective, ci și la îngăduința (sau bunăvoința) față de „dreptul la sens” al unui atare univers. De altminteri, această atitudine l-a caracterizat pe autor în toate demersurile sale interpretative, concretizate în mai multe cărți (avînd ca temă fie ipostazele raţiunii negative, fie „vocația eșecului”, fie „străinul” sau reprezentarea „celuilalt”, fie „metafizica de toate zilele” etc.).

În Cuvînt-înainte, Ștefan Afloroaei declară că a optat pentru „o privire mai curînd indirectă, speculativă” (p. 10). Termenul speculativ este luat aici ,într-o accepțiune simplă, aproape etimologică: a privi ceva ca în oglindă, în lumina caldă a îndepărtării, spre a vedea deopotrivă ceea ce este echivoc sau incomprehensibil, distanța însăşi care se tot reface” (p. 10). Nu criteriile ferme care să permită analize exacte ale situațiilor (aşa-zise) „absurde” îl interesează pe autor, ci „mai degrabă locul de unde [experiențele «lipsite de sens»] ar putea fi privite altfel” (p. 10). De bună seamă, de pe urma analizei logice a limbajului ar rezulta că ideile metafizice, viziunile religioase și multe dintre textele literaturii artistice sînt absurde sau lipsite de sens. Or (așa cum remarca John Dewey), în „oceanul de sensuri”, sensurile pe care le numim „adevăruri” (verificate și confirmate științific) reprezintă doar o „insulă”.

Ceea ce încearcă Șt. Afloroaei este să afle, pe de o parte, dacă se poate vorbi cu sens despre cele lipsite de sens și, pe de altă parte, dacă, într-adevăr, lumea se poate împărți în două zone: una a celor cu sens (cf. germ. sinnvoll) și alta a celor lipsite de sens (cf. germ. sinnlos) sau chiar absurde. O divizare tranșantă i se pare însă dificil de susţinut: „Greu de crezut aşa ceva. Cu toate acestea, voi avea în vedere tocmai cele ce apar într-un fel sau altul străine sensului, fie că e vorba de enunțuri, imagini și idei, fie de narațiuni sau întîmplări. Spun străine sensului, însă uneori apar lipsite de sens, alteori potrivnice sensului, absurde, eventual libere în privința sensului.” (p. 7). Prin urmare, sînt vizate experiențele care scapă înțelegerii obișnuite, care scandalizează gîndirea însăși. Totodată, autorul stabilește fine deosebiri de nuanță între termenii lipsit de sens, nonsens și absurd. În cazul lui absurd (provenind din lat. absurdum), este realizată chiar o veritabilă fișă lexicografică (vezi p. 9), înregistrînduse semnificațiile termenului, inclusiv în evoluția lor istorică (fapt ce va limpezi sensul posibil al unor enunțuri antice, cum găsim la p. 69-71, de pildă).

Se observă că exemplele examinate fac parte fie din „lumea cuvîntului” (texte sau enunțuri problematice), fie din „lumea vieții” (situații și evenimente problematice). Ele au fost extrase din paginile unor filozofi (precum Cicero și Tertulian, Pascal şi Kant, Nietzsche şi Kierkegaard, Heidegger şi Wittgenstein) sau din paginile unor scriitori socotiţi „admirabili” (precum Kafka și Borges). Practic, analizele lui Ștefan Afloroaei sînt orientate astfel: (i) către diverse situații absurde (la prima vedere) sau (pretins) lipsite de sens, cum sînt cele descoperite în proza scriitorilor de mai sus; (ii) către enunțuri (cel puțin) stranii formulate de unii gînditori (cum este, printre altele, propoziția Credo quia absurdum, pusă de tradiție pe seama lui Tertulian); (iii) către acei filozofi care au dovedit o anumită „apetență” sau sensibilitate pentru tema celor absurde/lipsite de sens și, în fine, (iv) către acei filozofi care, dimpotrivă, nu au privit cu prea multă simpatie/îngăduință un atare subiect („aparent mai sceptici”, cum îi încadrează

\footnotetext{
*Adresă de corespondență: munteanucristinel@yahoo.com.
} 
profesorul Afloroaei) ${ }^{1}$. În consecință, discuția se poartă la ambele niveluri: atît al faptelor ca atare, cît și al reflecțiilor despre acestea.

Cartea este construită în mod echilibrat, cuprinzînd patru secțiuni apropiate ca lungime: $L a$ frontierele celor absurde (p. 13-54); Limite ale comprehensiunii (p. 55-97); Apariții libere ale nonsensului (p. 99-143); Paradox și nonsens (p. 145-196). Simetria se vădește și în aceea că fiecare secțiune se împarte, la rîndu-i, în șase subsecțiuni, rezultînd, aşadar, un total de 24 de probleme discutate. Un Index nominum (p. 197-200) și un Index rerum (p. 201-214) completează în mod fericit lucrarea, sporindu-i utilitatea.

Exemplele alese și comentate cu subtilitate de Șt. Afloroaei sînt captivante. Pe spațiul mai multor pagini sînt analizate texte din Borges (cu o evidentă preocupare pentru ipostazele „labirintului” din opera acestuia). Nici Kafka nu este neglijat (autorul propunînd o interpretare originală a dificilului text $\hat{I} n$ fața legii). Dintre filozofi, Nietzsche, Wittgenstein și Kierkegaard beneficiază de o atenție specială. Este interesant că Ștefan Afloroaei caută să motiveze pînă și atitudinea sceptică sau de respingere manifestată de unii filozofi cu privire la universul celor absurde sau lipsite de sens (cum este și cazul lui Aristotel, a cărui intransigență, pe alocuri, trebuie explicată prin aversiunea sa față de derapajele sofiștilor).

Autorul mărturisește (la p. 11) că datorează mult lecturii unor scrieri semnate de Eugeniu Coșeriu, Umberto Eco, Arthur C. Danto şi Graham Priest. Dintre aceștia, cel mai prețuit pare a fi Eugeniu Coșeriu, dacă judecăm și după spațiul pe care îl ocupă în economia lucrării lui Șt. Afloroaei reproducerea ideilor coșeriene referitoare la absurd (vezi îndeosebi p. 134-142). Într-adevăr, Coșeriu a afirmat (și nu doar o dată) că dacă absurdul poate fi gîndit, el poate fi şi exprimat. De asemenea, a susţinut că despre irațional se poate discuta rațional; despre ceva absurd se poate vorbi într-un mod foarte coerent (de aceea, corect este să spunem că teatrul lui Eugène Ionesco este un teatru al absurdului, și nu un teatru absurd). Lingvistul de origine română a arătat (frecvent) în ce situații anumite enunţuri, socotite de logicieni drept absurdități tipice, au sens, fiind perfect acceptabile; în ce tipuri de discurs se întîlnesc aceste expresii, prin ce procedee iau naștere ș.a.m.d.

În acelaşi timp, nu pot să nu observ că atît Ștefan Afloroaei, cît și Eugeniu Coșeriu aplică în practica lor hermeneutică principiul încrederii, care presupune, totodată, o mare generozitate față de discursul/textul celuilalt: interlocutorul (chiar și în dialog „peste timp”) trebuie considerat, încă de la început, un om de bună credință, căruia se cuvine să-i acordăm ,prezumția de sens”; abia după ce vorbitorul cu pricina ne înșală grav așteptările, păcătuind prin nonsensurile exprimate, îi vom retrage încrederea acordată.

Înclin să cred că Ștefan Afloroaei este încă și mai generos/tolerant decît alți interpreți, după cum o dovedește subsecțiunea nr. 10 a cărții sale, subsecțiune intitulată Oameni absurzi și idei absurde (Kant). Aici autorul comentează unele afirmații kantiene (din Logica generală) în felul următor: „Deși oamenii pot sesiza în mod obișnuit ceva absurd, nu toți sînt atenți la prezența acestuia. În astfel de cazuri, ne spune Kant, nu e bine să-i aduci cuiva imediat o acuză, să-i spui verde în față că nu a înțeles cum se cuvine sau nu s-a exprimat corect logic. Mai potrivit ar fi să începi «prin a-i face evidentă această aparență ». A reproșa cuiva faptul că a comis o judecată absurdă «este întotdeauna un defect personal, care trebuie evitat». Dacă se convinge singur de eroarea săvîrșită, cel cu care discuţi este rezonabil. «Dacă persistă, atunci este desigur un om absurd; iar în această situație nu mai este nimic de făcut. El a devenit prin aceasta

\footnotetext{
${ }^{1}$ În acest context, aș menționa și cartea lui Andrei Cornea, O istorie a nefinței în filozofia greacă (Editura Humanitas, București, 2010), în care autorul se ocupă de felurile în care grecii antici au tratat problema neființei (a nimicului sau a neantului). După cum demonstrează Andrei Cornea, vechii greci au manifestat trei tipuri de atitudine în raport cu un atare subiect: (1) o atitudine/viziune anti-meontologică, (2) una meontologică și (3) alta ontologică. Foarte pe scurt, anti-meontologia interzice discursul despre neființă, meontologia (de la v.gr. mé ón 'neființă) îl acceptă (și îl practică), iar ontologia ignoră complet o asemenea temă de reflecție și de discuție. Mai trebuie spus că meontologia este preocupată, mai curînd, de „neființa secundă” (cum o numea Constantin Noica), și nu de „neființa primă” (adică nimicul sau neantul absolut). Ca să reiau o analogie lămuritoare oferită de Andrei Cornea, tăcerea în sine (ca absență a sunetului, dar și a muzicii) corespunde neființei prime, în timp ce pauza din discursul muzical corespunde neființei secunde. La fel, în semiotică şi în lingvistică, de pildă, așa-numitele „semne zero” (cum este și cazul „morfemului Ø” din gramatică) țin de o atare neființă secundă. O distincție similară operează și Ștefan Afloroaei atunci cînd face următoarea precizare într-o notă de subsol: „Am preferat să spun «lipsit de sens», și nu « fără sens», întrucît cele fără sens pot să apară—în anumite condiții—cu sens. În schimb, ceva lipsit de sens s-ar plasa dincolo de zona de posibilitate a celor cu sens și fără sens.” (Șt. Afloroaei, op. cit., p. 34). Cred că cele „lipsite de sens” s-ar încadra (în acest caz) în sfera neființei prime, iar cele „fără sens” s-ar include în sfera neființei secunde.
} 
incapabil și nedemn de alte corectări și respingeri. Căci unei persoane absurde nu i se poate demonstra propriu-zis nimic, orice argument ar fi zadarnic.»" (p. 77) $)^{2}$. Iată, am zice, o situație în care principiul încrederii încetează să se mai aplice, un caz în care încrederea acordată i-a fost retrasă interlocutorului...

Numai că Ștefan Afloroaei consideră că o astfel de concluzie (deși logică, pe cît se pare) este una „definitivă și oarecum tristă, gravă” (p. 77). Cele spuse de Kant în privința „omului absurd” îi oferă autorului prilejul formulării mai multor întrebări și reflecții (care dezvăluie, de fapt, propria-i manieră de lucru): „Să fie într-adevăr orice argument zadarnic în cazul acestui om? Dar există un asemenea om? Ne dăm seama că nimeni nu poate fi considerat absurd prin natura sa. Și nimeni nu e străin întru totul celor absurde. În acest caz, e curios că filozoful nu spune altceva în legătură cu situația de mai sus. Bunăoară, nu spune că ar trebui încercat de mai multe orieventual ori de cîte ori e cazul-să dovedești celui cu care discuți aparența adevărului. Nici că ar trebui să vezi dacă nu cumva are dreptate, fie prin una dintre intențiile sale, fie sub un înțeles distinct al celor exprimate. [...] Firesc ar fi, probabil, să te întrebi dacă nu cumva nonsensul afirmațiilor sale are o justificare, dacă nu cumva este mai elocvent decît sensul oferit în aceeași chestiune de simțul comun.” (p. 78-79).

Fără îndoială, această excelentă carte a filozofului Ștefan Afloroaei este o scriere din care se pot extrage foarte multe învățăminte. Ea nu se adresează numai celor care se îndeletnicesc cu filozofia. Sînt convins că, odată citită, ea va aduce beneficii de ordin spiritual și satisfacții intelectuale tuturor oamenilor de cultură.

\footnotetext{
${ }^{2}$ Citatele reproduse sînt din Immanuel Kant, Logica generală, traducere de Alexandru Surdu, Editura Științifică și Enciclopedică, București, 1985, p. 110.
} 